\title{
Red Flags to Detect Fraudulent Financial Reporting in Indonesian Banking Sector
}

\author{
Anggreni Dian Kurniawati \\ Accounting Study Program, Faculty of Business and Economics, Yogyakarta 55281, Indonesia \\ Email: anggreni.kurniawati@uajy.ac.id
}

\begin{abstract}
Indonesian banking sector suffer huge loss because of fraud. In some cases, perpetrators attempt to commit fraud concealment by conducting financial restatement, even though the financial statement information was used by stakeholders for decision making. As a consequence, this concealment can reduce the quality of financial statement information. Furthermore, the poor quality of financial statement information can reduce the level of accuracy of stakeholders in making economic decisions. Therefore, before fraud occurs, red flags must be detected early as an early warning of an ethical action taken to occur. The fraud pentagon approach can detect potential fraud that occurred through five components, namely pressure, opportunity, rationalization, competence, and arrogance. This study aims to examine the potentiality of fraud pentagon components as red flags to detect fraudulent financial reporting in Indonesian banking sector. This study conducted in banking sector companies that listed on the Indonesia Stock Exchange for the period 2015 to 2018. Logistic regression is used to empirically prove the research objectives. This research succeeded to prove that the higher pressure can increase the company to commit financial reporting fraud and the higher opportunity can reduce the company to commit financial reporting fraud. Nonetheless, the rationalization, competence and arrogance do not affect the company to commit financial reporting fraud. This results can provide recommendations to the Indonesian banking sector to strengthen their internal control systems and implement an anti-fraud program that is not just obeying the rules, but because of their awareness to obey them.
\end{abstract}

Keywords: banking sector, financial restatement, fraudulent financial reporting, fraud pentagon, red flags.

\section{INTRODUCTION}

Banking are the service companies need public trust to save their funds. Therefore, banks need to maintain integrity and act ethically in running their business. According to a survey conducted by the Association of Certified Fraud Examiners (ACFE) [1], in 2016, the banking and financial industry suffer huge loss because of fraud. Fraud that occurred in the Indonesian financial sector reached $43.1 \%$. In other word, this fact is an early warning for the Indonesian banking sector to improve integrity so that people do not lose their trust.

There are three main cases of fraud that need to be considered in business according to ACFE [2], such as corruption, asset misappropriation, and fraudulent financial reporting. This study focuses on fraudulent financial reporting. This fraud can be done by presenting financial statements not in accordance with the actual situation thereby reducing the quality of financial statement information. Incorrect financial statement information can mislead users of financial statements and make investment decisions inaccurate. Therefore, the red flags has to be known so as not to cause harm to various parties. In the Indonesian banking sector, the fraudulent financial reporting case was carried out by Bank Bukopin [3] who conducted financial restatement on its financial statements in 2015, 2016, and 2017 for allegedly making modifications to credit card data and the case could not be detected by internal auditors, an independent auditor, Bank Indonesia, and also the Otoritas Jasa Keuangan (OJK), and finally, the 
management found it. The financial restatement carried out by Bank Bukopin was carried out as a way to conceal fraud committed by perpetrators. Therefore, the financial restatements carried out by companies are suspected to be red flags for fraudulent financial reporting.

There are many factors cause individuals to commit fraud. Previous research related to fraud has been carried out by Cressey [4] who proposed three components of fraud namely pressure, opportunity and rationalization, which is then called the fraud triangle. This approach was later developed by Wolfe and Hermanson [5] who proposed four components of fraud, namely pressure, opportunity, rationalization, and capability, which became known as fraud diamond. Wolfe's approach is then refined again by Crowe Howarth [6] who explains the five components of fraud namely pressure, opportunity, rationalization, competence/capability, and arrogance, which become known as fraud pentagon. Weakness in the Crowe fraud pentagon approach is the proxy component of arrogance fraud using the narcissistic nature of the CEO. Therefore, Tugas [7] provides a pentagon fraud approach that is different from Crowe Howarth who replaces this arrogance component with external regulatory influence which is thought to be one of the components that causes fraud. This study uses a pentagon fraud approach carried out by the Tugas to analyse red flags fraudulent financial reporting conducted by banking companies in Indonesia which are listed on the Indonesian Stock Exchange.

The aim of this study was to examine the potentiality of fraud pentagon components as red flags to detect fraudulent financial reporting in Indonesian banking sector. This results can provide recommendations to the Indonesian banking sector to strengthen their internal control systems and implement an anti-fraud program that is not just obeying the rules, but because of their awareness to obey them.

\section{LITERATURE REVIEW}

Corporate fraud can occur and is explained by agency theory introduced by Jensen and Meckling [8]. The theory explains the relationship based on contracts that occur between members in the company, namely between the owner (principal) and management (agent) as the main actor. In the contract, the principal delegates some decisionmaking authority to the agent. There is a separation of ownership between the principal and agent in a company, so there is a possibility that the principal's wishes are ignored [9]. As a result, there was an asymmetric information between the agent and the principal because the management (agent) as the manager of the company has more information about the company than the owner or shareholder (principal). Asymmetric information is supported by conflicts of interest. It is because the agents want high compensation for their performance and principals want a high return on their investment. The management who has a greater opportunity to benefit because more information about the company under management raises moral hazard by conducting fraudulent financial reporting.
Based on the agency theory, in this case, managers are always required to generate certain profits or have financial targets to maintain the company's performance remains good or even improve it. In this study the pressure component is proxied by financial targets [10]. The higher the company's financial targets, the greater the profits obtained and the company's assets are used properly. The higher the target given for management, the greater the likelihood of fraudulent actions occurring due to pressure exerted on management to achieve these targets, the more it will encourage management to commit fraud. Therefore, the hypothesis of this study is as follows:

H1: Financial target has a positive effect on fraudulent financial reporting.

Effective supervision is one reflection of a good internal control system. According to SAS No. 99 [11], domination by individual or several people in a small group without compensation control makes supervision ineffective, resulting in poor internal control of the company. Ineffective monitoring and poor internal control of the company results in more opportunities for fraud.

Several previous studies have shown consistent results that ineffective monitoring has a positive effect on financial statement fraud, which means that the higher the ineffective monitoring, the greater the opportunity to commit fraud and the possibility of financial statement fraud is also greater, so the hypothesis of this study is as follows:

$\mathrm{H} 2$ : Effective monitoring has a positive effect on fraudulent financial reporting.

The third component of fraud, namely rationalization, is the attitude of someone who considers an action to be right so that there is a possibility that they will be involved and cover up fraud that occurs within the company. If the management continues to understand the minor frauds that occur and consider it a normal thing to do, then fraud will increase. Earnings management is an early indication of fraudulent financial reporting that occurs due to the impact of using the accrual principle in financial statements. Based on previous research, the higher the management justifies their fraud, the higher the possibility of fraudulent financial reporting, so the hypothesis is as follows:

H3: Rationalization has a positive effect on fraudulent financial reporting.

Change of company directors is an effort to improve company performance because the new board of directors is considered more competent than the old board of directors. However, the change of directors can be used as a red flag for fraud due to the company's efforts to get rid of those who know of fraud that occurs within the company. This change of directors caused a stress period that resulted in the company's performance becoming less effective so that the greater the opportunity to commit fraud. Several previous studies stated that the higher the turnover of directors 
conducted by a company, the red flag of the occurrence of fraudulent financial reporting is also higher. Therefore, the hypothesis of this research is as follows:

H4: Change of directors has a positive effect on fraudulent financial reporting.

External regulations that bind companies are usually effective in preventing fraud. In Indonesia, the Financial Services Authority requires banks to form work units tasked with handling the implementation of anti-fraud strategies to control fraud risk. Banking companies that have anti-fraud strategies can be interpreted to have good internal control, so fraud can be prevented before they occur. Previous research [12] showed that banking anti-fraud strategies had a negative effect on fraudulent financial reporting, the better the application of anti-fraud strategies, then fraud could be minimized. Therefore, the hypothesis of this research is as follows:

H5: Anti-fraud strategies has a negative effect on fraudulent financial reporting.

\section{RESEARCH METHOD}

This study uses all banking companies listed on the Indonesia Stock Exchange in the period 2015-2018. The sample selection using the purposive sampling method. The criteria are this study use annual report of banking sector companies listed on the Indonesia Stock Exchange for the period 2015-2018 must have data relating to the research variables that are presented in full and use the IDR currency. Based on these criteria, there were 42 banking companies for the sample.

The dependent variable used in this study is fraudulent financial reporting. Fraud in financial statements is done to deceive the users of the financial statements with the misstatements disclosure or the neglect of the amount [13]. Based on this statement, the fraudulent financial reporting variable uses a restatement proxy using a dummy variable where 1 if there is a restatement and 0 if no restatement occurs.

The independent variables used in this study are financial targets measured by ROA; ineffective monitoring as measured by the proportion of the board of directors; rationalization with total accruals; change of directors with a dummy variable where 1 if there is a change in directors and 0 if there are no directors change; and banking antifraud strategies with a dummy variable where 1 if the company submits in the financial statements an anti-fraud strategy and 0 if the company does not submit in the antifraud strategy financial statements [14].

This study has a dependent variable with nominal data, therefore, in this study using logistic regression. Before testing the hypothesis, it is necessary to see the feasibility of the regression model and the coefficient of determination. The feasibility of the regression model was tested using Hosmer and Lemeshow's goodness of fit test, while the coefficient of determination was taken from the Nagelkerke $\mathrm{R}^{2}$ value. The error rate or margin of error $(\alpha)$ used in this study is $5 \%$. The regression equation used to test the hypothesis in this study is as follows:

\begin{tabular}{|c|c|}
\hline FFR & Froudulant Financio \\
\hline Repc & \\
\hline керс & Constant \\
\hline b1 & $\begin{array}{l}\text { : Coefficient regression of } \\
\text { financial target }\end{array}$ \\
\hline b2 & $\begin{array}{l}\text { : Coefficient regression of } \\
\text { ineffective monitoring }\end{array}$ \\
\hline b3 & $\begin{array}{l}\text { : Coefficient regression } \\
\text { of rationalization }\end{array}$ \\
\hline b4 & $\begin{array}{l}\text { Coefficient regression of director } \\
\text { change }\end{array}$ \\
\hline $\begin{array}{l}\text { b5 } \\
\text { strategy }\end{array}$ & : Coefficient regression of anti-fraud \\
\hline ROA & : Financial target \\
\hline BDOUT & : Ineffective Monitoring \\
\hline TATA & : Rationalization \\
\hline DCHANGE & : Pergantian direksi \\
\hline ANTIFRAUD & : Strategi Anti-Fraud \\
\hline Perbankan e & : error \\
\hline
\end{tabular}

\section{RESULT AND DISCUSSION}

\subsection{Data Analysis}

Descriptive statistics analysis presents an overview of the variables in this study by looking at the minimum, maximum, mean, and standard deviation values. The results of the descriptive statistics in this study are as follows: 
Table 1 Descriptive Statistic

\begin{tabular}{lccccc}
\hline & N & Min. & Max. & Mean & $\begin{array}{c}\text { Std. } \\
\text { Dev }\end{array}$ \\
\hline ROA & 168 & -0.12 & 0.03 & 0.003 & 0.022 \\
BDOUT & 168 & 0.40 & 1.00 & 0.584 & 0.104 \\
TATA & 168 & -0.14 & 0.49 & 0.009 & 0.074 \\
DCHANGE & 168 & 0.00 & 1.00 & 0.680 & 0.468 \\
ANTI & 168 & 0.00 & 1.00 & 0.740 & 0.438 \\
FRAUD & & & & & \\
FFR & 168 & 0.00 & 1.00 & 0.560 & 0.498 \\
\hline
\end{tabular}

Regression analysis used in this study is logistic regression using binary logistic regression. The data processed in this study are 168 data consisting of 42 companies in a period from 2015-2018. Below are the results of the model feasibility test using the Hosmer and Lemeshow's test

\section{Table 2 Hosmer and Lemeshow's Test}

\begin{tabular}{rrrr} 
Chi- & df & & Sig. \\
& & & \\
square & & & \\
\hline 4.220 & 8 & 0.837 \\
\hline
\end{tabular}

The results of the Hosmer and Lemeshow's test above are the chi-square count of 4.220 and the value of the chi square table is 9,488. Based on the chi-square value, 4.220 $<9,488$ and based on the Sig. 0.837> 0.05 which means that the model is fit for use in conducting tests related to the potential fraudulent financial reporting in banking sector companies. The Log -2 Likelihood value is used to measure the goodness of the estimate in logistic regression. The table below shows the value of -2 Log Likelihood when the independent variable has not been entered into the model (Block Number $=0$ ) and when the independent variable has been entered into the model (Block Number $=$ $1)$.

Table 3 -2 Log Likelihood Result

\begin{tabular}{cc}
\hline Block Number $=\mathbf{0}$ & Block Number $=\mathbf{1}$ \\
\hline-2 Log Likelihood & -2 Log Likelihood \\
230.511 & 217.905 \\
\hline
\end{tabular}

From the results of the feasibility test for the entire model above, the value of -2 Log Likelihood before the independent variable is entered (Block Number $=0$ ) is 230.511 and after the independent variable is entered into the model (Block Number $=1$ ) is 217.905. The Log Likelihood value decreased when the independent variable was entered into the model by 12,606 . This decrease in value means that the addition of the five independent variables in the model means that it shows a better regression model.

In logistic regression, the coefficient of determination $\left(\mathrm{R}^{2}\right)$ is called Pseudo $\mathrm{R}^{2}$. The coefficient of determination in logistic regression is described by the value of Nagelkerke $\mathrm{R}$ Square. Below is a table of determination coefficient test results. 
Table 4 Nagelkerke R Square Result

\begin{tabular}{ll}
\hline -2 Log Likelihood & Cox \& Snell R \\
& Nagelkerke R Square
\end{tabular}

\begin{tabular}{lcc}
\multicolumn{3}{c}{ Square } \\
\hline $\mathbf{2 1 7 . 9 0 5}$ & 0.072 & 0.097 \\
\hline
\end{tabular}

From the table above, we get the Nagelkerke R Square value of 0.097 or $9.7 \%$. That means the independent variable in this study can explain the dependent variable by $9.7 \%$. Thus, there are $90.3 \%$ of other independent variables that can explain the dependent variable outside this research model, such as financial stability, institutional ownership, auditor change and others

\subsection{Hypotheses Test Result and Discussion}

Hypothesis testing in logistic regression can be done by looking at the logistical coefficient test results by comparing the Sig. in the table with the significance value used. In this study the significance value used was $5 \%$ or 0.05 . Hypothesis test results in this study are shown in the table below :

Table 5 Hypotheses Test Result

\begin{tabular}{lccc}
\hline & B & Std. & Sig. \\
& & & \\
& & Error & \\
\hline ROA & 16.816 & 7.892 & 0.033 \\
BDOUT & -3.314 & 1.670 & 0.047 \\
TATA & -1.585 & 2.182 & 0.468 \\
DCHANGE & -0.586 & 0.356 & 0.099 \\
ANTIFRAUD & 0.507 & 0.407 & 0.213 \\
Constant & 2.203 & 0.965 & 0.022 \\
\hline
\end{tabular}

Based on the results of testing the regression coefficients in the table above, the regression equations obtained in this study are:

$$
\begin{gathered}
\text { FFR }=2,203+16,816 \text { ROA }-3,314 \mathrm{BDOUT}- \\
1,585 \mathrm{TATA}-0,586 \mathrm{DCHANGE}+0,507 \text { ANTIFRAUD }
\end{gathered}
$$

Based on the results of the hypothesis test, the regression results on the target financial variable obtained a significance value of 0.033 and the coefficient value was 16.816. The significance value is $0.033<0.05$ and the significance value is positive. This explains that the first hypothesis is accepted that financial targets have a positive effect on fraudulent financial reporting. The results obtained in accordance with the hypothesis that the higher the target set to be achieved by the management, the pressure felt by management is also increasing. Because of the pressure to reach a certain target, the possibility of management committing fraud is even higher.

The ROA value used as a proxy in this study explains that the lower the value of ROA means the lower net income obtained by the company as well. If the net income is low and does not meet the targets given to management, the perceived pressure is even higher because management has the responsibility to improve the company's financial condition to achieve its targets. The possibility of committing fraud is even greater with the pressure felt by the management. Management can manipulate financial statements or accounting policies used by companies to show high net income.

The second variable, ineffective monitoring, the coefficient value is -3.314 and the significance value is 0.047 . The significance value is $0.047<0.05$ and the significance value is negative. Thus, the second hypothesis in this study is not accepted that ineffective monitoring has a negative effect on the potential fraudulent financial reporting. The results shown are contrary to the hypothesis taken from this study that ineffective monitoring has a positive effect on the potential fraudulent financial reporting. The increasing number of independent commissioners, supervision and internal control of the company may be better because the independent commissioners come from outside the company itself.

The large number of independent directors will increase the company's internal control system so that the potential for fraud will be even lower. The possibility of fraud will be 
more likely if there is power in the hands of insiders [15]. The more independent commissioners are in a company, it will reduce the dominance of certain people. The results obtained are in accordance with the theory in SAS No.99 which states that the opportunity is partly due to ineffective monitoring. Thus, it can be concluded that the potential for fraud will increase if there is a lack of independence in the board of commissioners company.

The results for the rationalization variable obtained a coefficient value of -1.585 and a significance value of

0.468 . Significance value of $0.468>0.05$, which means the third hypothesis is not accepted and rationalization does not affect the potential fraudulent financial reporting. Rationalization or justification for errors made or known is suspected to be one of the factors of fraud in the financial statements. In the banking sector, anti-fraud regulations that must be used by banks help reduce the attitude of rationalization because in the anti-fraud strategy the bank already sets the detection steps. The good implementation of anti-fraud strategy, internal auditors and independent auditors who are effective in conducting surveillance, the possibility of rationalization can be further suppressed. In addition, there is a possibility that the company is not only based on the company's total accruals in making the decision to present financial statements. Management policy in conducting rationalization to justify fraud or manipulation of earnings is not high which means that the integrity of management is quite high. The results of this study are in line with research by Skousen. et, al. [10] which states that rationalization in a company is difficult to measure. With high integrity in everyone in the company, the possibility of fraud can be reduced.

The results for the change of directors variable, the coefficient value is -0.586 and the significance value is

0.099 . The significance value is $0.099>0.05$ which means the forth hypothesis is not accepted and explains that the change of directors has no effect on the potential fraudulent financial reporting. Change of directors in a company can be done for several reasons, because the term of office has expired, because of death, or because the directors in office indeed resigned. In addition to having expired terms of office, the change of directors was made to replace those with more competent and able to improve company performance in the following years. Someone who is more competent and has good loyalty to the company has a small possibility of commit fraud. Based on observations made, the term of office of directors in a bank is 3 to 5 years. A director who is able to manage the company well will have little possibility to be replaced before his term ends. During 2015-2018, the replacement of existing directors was largely due to the term of office that had already expired. Thus, directors have good competence in managing the company and the change of directors has no influence on the potential fraudulent financial reporting.

The results for the variable implementation of the banking anti-fraud strategy obtained a significance value of 0.213 and a coefficient value of 0.507 . The significance value is $0.213>0.05$ which means that the fifth hypothesis is not accepted and shows that the implementation of the banking anti-fraud strategy has no effect on the potential fraudulent financial reporting. The implementation of the anti-fraud strategy was required by Bank Indonesia in 2011 through Surat Edaran Bank Indonesia [16]. With the implementation of this anti-fraud strategy, it is hoped that banks will be able to control the risk of fraud by effective control and policy. In the research year 2015-2018, many banks had implemented an anti-fraud strategy following the rules of Bank Indonesia. However, in the Surat Edaran Bank Indonesia in 2011, it was stated that the success of the antifraud strategy was influenced by an environment that supported the creation of conducive conditions. In order to create an effective and conducive corporate environment, there are three supporting aspects of risk management namely active management supervision, organizational structure and accountability, control and monitoring, banks must take focused steps to improve the effectiveness of the implementation of anti-fraud strategies.

Banks that implement anti-fraud strategies but do not create a conducive and effective environment for their implementation are less likely to succeed. A good anti-fraud strategy has four pillars in it, such as:

1. Prevention, can be done by giving outreach to all employees.

2. Detection, can be done with a surprise audit and a whistleblowing system.

3. Investigation, reporting, and sanctions, namely banks have a good mechanism against fraud that occurs that the perpetrators of fraud will acted on and given sanctions.

4. Monitoring, evaluation, and follow-up, namely banks need to maintain data on fraud events and conduct evaluations to improve internal control.

For example, Bank Bukopin which is during the study period from 2015-2018, implemented an anti-fraud strategy, but found the potential for fraudulent financial statements on its credit card data. This can occur because a conducive environment is not created or the application of anti-fraud strategy pillars is inappropriate because for four years, Bank Bukopin has only implemented two pillars, namely prevention and detection. This explains that the application of the banking anti-fraud strategy does not affect the potential fraudulent financial reporting.

\section{CONCLUSION}

Based on the results of data analysis conducted, the conclusion obtained is that the financial target has a positive effect on the potential for fraudulent financial reporting and ineffective monitoring has a negative effect on the potential for fraudulent financial reporting. This study did not succeed in proving that rationalization, change of directors and the application of anti-fraud strategies affect the potential fraudulent financial fraud. Thus, financial targets and ineffective monitoring are red flags for fraudulent financial reporting in the Indonesian banking sector.

In this study the results obtained that the financial statements alone are not able to describe the actual 
condition of the company. Companies that are said to be good because they get high profits may not necessarily have good internal controls in dealing with fraud in the financial statements. The integrity of management and other authorized parties in the company determines whether there is a potential fraudulent financial fraud in the company or not. For banking sector companies, it is expected to prevent financial statement fraud by increasing internal control of the company, one of them is by employing people with high integrity so that the control system that has been run can run effectively.

This study has limitations, namely the selection of an appropriate proxy to see the effect of pentagon fraud on fraudulent financial reporting because the proxy contains elements of the perpetrator's behavior. Therefore, in subsequent studies, it should use behavioral elements that are reflected in financial reporting using a socio-linguistic approach that can interpret behavior through the strategies that companies disclose in their financial statements.

\section{REFERENCES}

[1] Assosiation of Certified Fraud Examiners (ACFE), in: Report to the Nations: 2016 Global Study on Occupational Fraud and Abuse, 2016.

[2] Assosiation of Certified Fraud Examiners (ACFE), in: Report to the Nations: 2020 Global Study on Occupational Fraud and Abuse, 2020.

[3] Sugianto, OJK Mulai Periksa Laporan Keuangan Bank Bukopin yang Dipermak, in: finance.detik.com. 2018. https://finance.detik.com/moneter/d4002904/ojk- mulai-periksa-laporan- keuanganbank-bukopin-yang- dipermak

[4] D.R. Cressey. Other's People Money, in: Patterson Smith, Montclair, New Jersey, 1953.

[5] D.T. Wolfe, D.R. Hermanson. The Fraud Diamond: Considering the Four Elements of Fraud, in: The CPA Journal 74 (12), 2020, pp. 3842.

[6] C. Horwarth. The Mind Behind The Fraudsters Crime: Key Behavioral and Environmental Element, in: Crowe Howart International, United State of America, 2012.
[7] F.C. Tugas, Exploring a New Element of Fraud: A Study on Selected Financial Accounting Fraud Cases in the World, in: American International Journal of Contemporary Research Vol. 2 No. 6, June 2012, pp. 112-12.

[8] M.C. Jensen, W.H. Meckling, Theory of the Firm: Managerial Behavior, Agency Costs and Ownership Structure, in: Journal of Financial Economics, 1976.

[9] J. Godfrey. A. Hodgson, A. Tarca, K. Holmes, J. Hamilton. Accounting Theory (7th edition), in: John Wiley and Sons, Milton, Australia, 2010.

[10] C.J. Skousen. Detecting and Predicting Financial Statement Fraud: The Effectiveness of The Fraud Triangle and SAS No. 99, in: SSRN, 2008.

[11] AICPA. Consideration of Fraud in a Financial Statement Audit, in: AU Section 316.

[12] M.A.R. Saputra, N.D. Kesumaningrum. Analisis Faktor-faktor yang Mempengaruhi Fraudulent Financial Reporting dengan Perspektif Fraud Pentagon pada Perusahaan Perbankan yang Terdaftar di Bursa Efek Indonesia tahun 20112015, in: Jurnal Akuntansi dan Keuangan, Vol. 22 No. 2, July 2017, pp. 121-134.

[13] A.J. Pearce, B.R. Robinson. Manajemen Strategis - Formulasi, Implementasi dan Pengendalian, in: Salemba Empat, Jakarta, Indonesia, 2008.

[14] C. Tessa, P. Harto. Fraudulent Financial Reporting: Pengujian Teori Fraud Pentagon pada Sektor Keuangan dan Perbankan di Indonesia, in: Simposium Nasional Akuntansi XIX, 2016.

[15] G.A.E, Putri, N.L.G. Sulindawati, A.T. Atmadja. Pengaruh Financial Targets dan Ineffective Monitoring terhadap Terjadinya Fraud (Studi Kasus pada Koperasi Serba Usaha Dana Pertiwi Seririt, Kecamatan Seririt, Kabupaten Buleleng, Provinsi Bali) in: e-journal Universitas Pendidikan Ganesha, June 2017.

[16] Surat Edaran Bank Indonesia No. 13/28/DPNP. Penerapan Strategi Anti Fraud bagi Bank Umum, in: www.bi.go.id., June 2020. 